\title{
In-Situ Environmental TEM Studies to Understand the Effect of Ru Promotion on Supported Ni Catalysts
}

\author{
S. Chenna,* and P.A. Crozier* \\ * School of Mechanical, Aerospace, Chemical and Materials Engineering, Arizona State University, \\ Tempe, AZ 85287-6106
}

Bimetallic catalysts sometime exhibit superior properties than the individual monometallic catalysts. Noble metals are in general highly active but they are expensive. A combination of noble metal with an inexpensive metal is an ideal case of improving the catalyst performance and at the same time keeping the materials cost low. In the present study we are performing partial oxidation of m ethane (POM) on $\mathrm{SiO}_{2}$ supported Ni-Ru bimetallic catalysts for syngas $\left(\mathrm{CO}+\mathrm{H}_{2}\right)$ production. The catalytic properties of the bim etallic catalysts depend on the s tructure and co mposition of the individual nanoparticles which can change significantly when they are exposed to reacting gases. It is important to understand the evolution of bi metallic nanoparticles under reacting gas c onditions in order get insights into its catalytic properties. We are perform ing catalytic measurements in parallel with insitu environmental TEM (ETEM) studies on Ni-Ru bim etallic catalysts in order to understand the effect of $\mathrm{Ru}$ promotion on Ni catalyst for POM reaction.

$\mathrm{Ni}-\mathrm{Ru} / \mathrm{SiO}_{2}$ bimetallic catalysts were prepared by in cipient impregnation method, according to the procedures given in Banerjee et al [1 ], by taking a solution containing $\mathrm{Ni}\left(\mathrm{NO}{ }_{3}\right)_{2} \cdot 6 \mathrm{H}_{2} \mathrm{O}$ and $\mathrm{RuCl}_{3}$ together. The final metal loading of the catalys t contains $2.25 \mathrm{wt} \% \mathrm{Ni}$ and $0.025 \mathrm{wt} \% \mathrm{Ru}$. Catalytic measurements were performed in an In-Situ Research Instruments RIG-150 reactor and the effluent gases were analyzed with an online Varian 3900 gas chrom atography system. STEM and EDX analysis on bimetallic catalyst were performed in a JEOL 2010 transm ission electron microscope to study the com positional variations in the individual nanoparticles. In-situ environmental TEM experiments were performed in an FEI Tecnai F-20 transmission electron microscope equipped with a differential pumping system to hold the gas pressures inside the environmental cell.

Figure la shows a Z-contrast STEM image of $\mathrm{Ni}-\mathrm{Ru} / \mathrm{SiO}_{2}$ after the reduction step along with an EDX spectrum of a typical individual nanoparticle showing the presence of both $\mathrm{Ni}$ and $\mathrm{Ru}$ in the nanoparticle. Figure $1 \mathrm{~b}$ shows the catalytic performance $\mathrm{Ni}-\mathrm{Ru} / \mathrm{SiO}_{2}$ catalysts. Complete combustion of up to $19 \%$ of the $\mathrm{C} \mathrm{H}_{4}$ takes place in the temperature range $300{ }^{\circ} \mathrm{C}$ to $560{ }^{\circ} \mathrm{C}$ giving $\mathrm{CO}_{2}$ and $\mathrm{H}_{2} \mathrm{O}$. A sudden increase in $\mathrm{CH}_{4}$ conversion and $\mathrm{CO}$ selectivity is observed at $585^{\circ} \mathrm{C}$ with an $\mathrm{O}_{2}$ conversion of $97 \%$. Above $585{ }^{\circ} \mathrm{C}$ both $\mathrm{CH}_{4}$ conversion and $\mathrm{CO}$ selectivity gr adually increase with increasing temperature. The presence of $\mathrm{Ru}$ ha $\mathrm{s}$ lowered the activation temperature for syngas production by $190^{\circ} \mathrm{C}$ compared to pure Ni catalyst [2 ]. From the reactor data it suggests that the gas environm ent around the catalyst bed varies with increase in temperature. In-situ ETEM experiments under variety of gas environments must be perform ed in order to understand the effect of $\mathrm{Ru}$ promotion on the catalyst performance. Figure $2 \mathrm{a}$ and $2 \mathrm{~b}$ shows the in-situ ETEM images of $\mathrm{Ni}-\mathrm{Ru} / \mathrm{SiO}_{2}$ at $400{ }^{\circ} \mathrm{C}$ in the presence of 1 Torr of $\mathrm{H}_{2}$ and $\mathrm{CH}_{4}+\mathrm{O}_{2}$ mixture (in 2:1 ratio) resp ectively. The nanoparticles transformed to void like structures when the gas composition is changed from $\mathrm{H}_{2}$ to mixture of $\mathrm{CH}_{4}$ $+\mathrm{O}_{2}$. Similar observations were found in case of pure Ni catalyst, where the void-structures are $\mathrm{NiO}$ [2]. Figure 2c is an in-situ electron energy-loss spectrum from the void structure nanoparticle in the presence of $\mathrm{CH}_{4}+\mathrm{O}_{2}$, shows the $\mathrm{O}$-Kedge and $\mathrm{Ni}-\mathrm{L}_{2,3}$ edge. The EELS proves that the nanoparticle 
has been transformed to $\mathrm{NiO}$ and shows that $\mathrm{Ru}$ does not inhibit the form ation of $\mathrm{NiO}$ at $400{ }^{\circ} \mathrm{C}$ in the $\mathrm{CH}_{4}$ and $\mathrm{O}_{2}$ atmosphere. However, at higher tem peratures, $\mathrm{Ru}$ may facilitate reduction of $\mathrm{Ni} \mathrm{O}$ back to Ni permitting syngas formation at lower temperatures compared to pure Ni. We will present the in-situ ETEM results on the effect of Ru promoti on on structure and phase of Ni nanoparticle $\mathrm{s}$ under other reacting gas conditions and its influence on the catalysts performance will be discussed.

\section{References}

[1] R. Banerjee et al., Microsc. Microanal. 15 (Suppl. 2) (2009) 732.

[2] S. Chenna et al., ChemCatChem, n/a, doi: 10.1002/cctc. 201000238.

[3] The support from the National Science Foundation (NSF-CBET-0553445) and the use of TEM at the John M. Cowley Center for High Resolution Microscopy at Arizona State University are gratefully acknowledged.
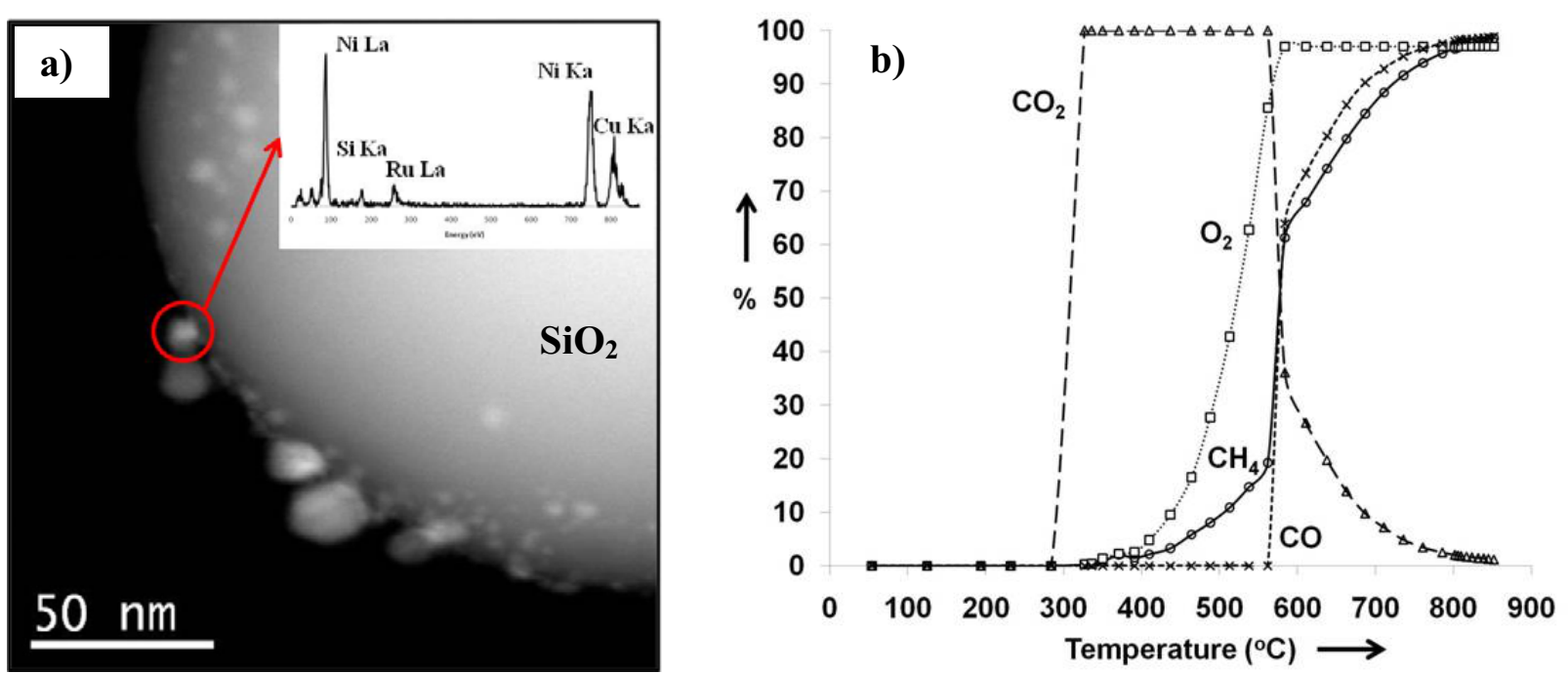

FIG. 1. a) $\mathrm{STEM}$ im age of $\mathrm{Ni}-\mathrm{Ru} / \mathrm{SiO}_{2}$ catalyst along with the $\mathrm{E} \mathrm{DX}$ spectrum from individual nanoparticle showing the presence of both $\mathrm{Ni}$ and $\mathrm{Ru}$. b) Plot showing $\mathrm{C} \mathrm{H}_{4}$ and $\mathrm{O}_{2}$ conversion and its selectivity towards $\mathrm{CO}$ and $\mathrm{CO}_{2}$ during the temperature ramp-up of b) $\mathrm{Ni}-\mathrm{Ru} / \mathrm{SiO}_{2}$ catalyst.
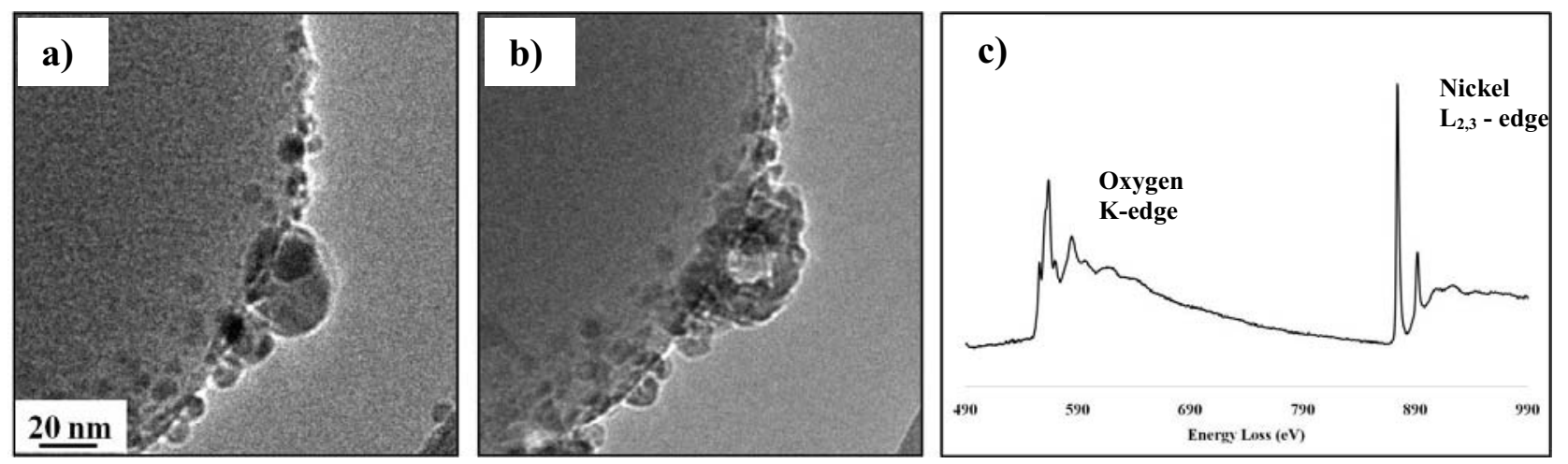

FIG. 2. a) and b) In-situ ETEM images of $\mathrm{Ni}-\mathrm{Ru} / \mathrm{SiO}_{2}$ catalyst at $400^{\circ} \mathrm{C}$ in presence of 1 Torr of $\mathrm{H}_{2}$ and $\mathrm{CH}_{4}+\mathrm{O}_{2}$ mixture (in 2:1 ratio) respectively, c) In-situ EELS from a void structured nanoparticle at $400^{\circ} \mathrm{C}$ in the presence of $\mathrm{CH}_{4}+\mathrm{O}_{2}$ mixture. 